\title{
A SURVEY OF ABANDONMENT OF STUDENT NURSES AT GREYS HOSPITAL
}

\author{
S.F FRY R.N. R.M. D.N. Ed. \\ Tutor, Greys Hospital, Pietermaritzburg. \\ A. KARANI B.Sc. HONS, M.Sc \\ Clinical Psychologist/Lecturer, Midlands Hospital, Pietermaritzburg. \\ G.M. TUCKELL R.N. R.M. R.Psy. D.N. Ed. \\ Matron, Greys Hospital, Pietermaritzburg.
}

\section{OPSOMMING}

'n Opname is gedoen onder voormalige studentverpleegkundiges van een hospitaal om die faktore wat met die hoë stakingssyfer verband hou te bepaal.

Die volgende is enkele van die belangrikste bevindings:

- daar was betekenisvolle ontevredenheid oor werksomstandighede in die algemeen;

- 'n klein maar betekenisvolle groep kon nie met die akademiese eise van verpleegkunde tred hou nie:

- dit blyk of interpersoonlike verhoudings tot 'n groot mate tot studente se besluit om te staak bygedra het;

- daar was 'n gebrek aan persoonlike en professionele ondersteuning;

- 'n vorm van tussentrede sou moontlik staking by 'n aantal van die studente kon voorkom het.

Verdere navorsing oor elk van die aspekte wat in hierdie studie aangeraak is, is nodig. Uit hierdie navorsingsprojek kan egter reeds afgelei word dat die probleem van hoẻ stakings op twee vlakke aangepak behoort te word, naamlik op individuele hospitaalvlak en op 'n breër vlak om werksomstandighede te verbeter.

\section{INTRODUCTION}

In all tertiary education, a certain percentage of drop-outs can be expected. In this instance, the authors were interested in the abandonment or withdrawal of students from the Diploma in General Nursing at Greys Hospital, Pietermaritzburg. Over the past few years the dropout rate at Greys Hospital was sufficiently high to cause concern particularly at a time when there is a widely reported shortage of White nursing personnel. Also, in the South African context, very little active research has been reported in this regard.

According to Birch $(1975)^{1}$ it is important to gain access to dropouts to discover precisely what they thought of training methods; details of personal relationships; frustrations encountered and also to attempt to understand their point of view. The problem of abandonment by nursing students has existed for many years throughout the world. Researchers have been preoccupied with attempting to demonstrate variables such as age of entry, hours of duty, the hospital environment, study demands, restrictions on social life, etc. Macquire $(1969)^{2}$, in his review of the literature, concludes that the attempt to demonstrate the relationship of the above factors to withdrawal separately has not been particularly successful. Therefore, the purpose of the survey under discussion was to broadly investigate some of the factors which may be related to withdrawal in the South African context, without attempting to demonstrate any specific variables per se.

\section{METHOD}

A pilot study was conducted with 28 student nurses at Greys College in order to evaluate the questionnaire designed for this study. The questionnaire was evaluated with regard to it's validity and practicality.

The sample comprised those drop-outs who had commenced training at Greys Hospital in the period January 1976 to December 1979. During this period 224 students, out of a total intake of 600 , abandoned training, hence giving a drop-out rate of $37,3 \%$. The revised questionnaire was posted to these 224 drop-outs.

After a month had elapsed a reminder and a second copy of the questionnaire were posted to those who had not responded. After a period of six months there was a total of 164 respondents, which represented $73,54 \%$ of the sample. Nineteen questionnaires were regarded as spoilt and thus a total of $145(65,02 \%)$ questionnaires were evaluated. It may be relevant to point out that some questions were unanswered in a few of the returns. This was however accounted for in the analysis of the questionnaires. 


\section{RESULTS}

\section{Demographic Data}

Tables 1 and 2 reflect some basic demographic data

\section{Service and Working Con- ditions}

Possibly one of the more important results of this study is the data on service and working conditions (such as salary, hours of duty, weekend and night duty). The following factors which are of specific interest emerged:

- regarding hours of duty, $63,7 \%$ of the abandon group indicated that their duties generally interfered with their social life and activities. A further breakdown in this respect is provided in Table 3.

It is interesting to note that upon admission to the course, $65,5 \%$ of the students indicated that they were aware that nursing would affect their social life and activities;

- the response to the question concerning the abandon groups' opinion of the salary structure for student nurses and registered nurses is shown in Table 4.

TABLE 1: THE TOTAL GROUP RECRUITED

\begin{tabular}{l|c|c}
\hline VARIABLE & MEAN AGE & TOTAL \\
\hline $\begin{array}{l}\text { SCHOOL LEAVER } \\
\text { PREVIOUS WORK EXPERI- } \\
\text { ENCE }\end{array}$ & 17,91 years & $462(77 \%)$ \\
\hline & 21,46 years & $138(23 \%)$ \\
\hline
\end{tabular}

TABLE 2: ABANDON GROUP AND NON-ABA.NDON GROUP

\begin{tabular}{l|l|l}
\hline VARIABLES & $\begin{array}{l}\text { ABANDON GROUP } \\
\mathrm{N}=224(37,3 \%)\end{array}$ & $\begin{array}{l}\text { NON-ABANDON GROUP } \\
\mathrm{N}=376(62,7 \%)\end{array}$ \\
\hline MEAN AGE & 18,5 years & 18,7 years \\
$\begin{array}{l}\text { MEAN PERIOD IN TRAIN- } \\
\text { ING }\end{array}$ & 11,7 months & 36 months \\
PREVIOUS WORK EXPERI- & $48(21,4 \%)$ & $90(23,9 \%)$ \\
\hline ENCE &
\end{tabular}

\section{TABLE 3: ANALYSIS OF RESPONDENTS COMPLAINTS RE-} GARDING HOURS OF DUTY

\begin{tabular}{l|c}
\hline COMPLAINT & \% OF RESPONDENTS \\
\hline DAY DUTY HOURS WERE INCONVENIENT & 23,5 \\
SPECIFIED WEEKEND DUTY AS INCON- & 16,7 \\
VENIENT & 14,7 \\
SPECIFIED NIGHT DUTY AS INCONVENIENT & $\mathbf{8 , 8}$ \\
WORK TIRING AND NO ENERGY AFTER & \\
HOURS
\end{tabular}

TABLE 4: ANALYSIS OF RESPONDENTS OPINIONS REGARDING SALARY STRUCTURES

\begin{tabular}{l|c|c}
\hline RANK & SALARY ADEQUATE & \\
\hline STUDENT NURSES & $43,4 \%$ & \\
REGISTERED NURSES & $1.4 \%$ & $54,5 \%$ \\
\end{tabular}

Regarding whether or not salaries had influenced their decision to abandon training, $22,1 \%$ of the respondents indicated that the salary structure had influenced them directly.

\section{Theoretical Education at the Nursing College}

In respect of the theoretical education at the nursing college, $67,6 \%$ of the respondents were of the opinion that their college preparation was adequate for clinical exposure at ward and department level.

However, $23,4 \%$ felt that they were inadequately prepared as there was no correlation between theory and practice and the college could not satisfactorily simulate the actual clinical setting. Some of the respondents specifically stated feelings of academic inadequacy. Nevertheless, when it came to actually putting into practice their theoretical education, whether adequate or not, $77,9 \%$ indicated that they received enough help from either the clinical instructors or the ward nursing staff. Consequently the majority $(80 \%)$ found working in the wards a rewarding experience. A relevant point here is the fact that prior to commencement of training most of the students $(93,1 \%)$, were cognisant of the fact that the diploma course would involve studying.

\section{Experiences directly con- tributing to abandonment}

With regard to the actual area of experience that contributed directly to respondents' abandonment of the course, the following emerged:

\section{WARD/DEPARTMENT EXPERI- ENCE $(\mathbf{4 0} \%)$}

Significantly, $40 \%$ of the abandon group indicated that experiences in the ward/department were directly responsible for their abandonment. Specific mention was made of poor interpersonal relationships at the nursing team level; unduly critical attitudes of ward nursing staff; degradation in the presence of patients; situational demands such as cancer or death and other stresses beyond their personal coping mechanisms. 


\section{NURSING COLLEGE $(32,5 \%)$}

Feelings of inadequate preparation and lack of academic ability were expressed. Some indicated that they were poorly treated by the tutorial staff.

\section{NURSES' HOME $(23,5 \%)$}

It was indicated that the nurses' home was not geared to meeting the needs of young adults. Other complaints were that the home was like a prison; feelings of loneliness were expressed; a lack of privacy was experienced and the hospital atmosphere was inescapable.

\section{PERSONAL REASONS $(21,4 \%)$}

Here the reasons were of a personal nature, e.g. marriage.

\section{Interpersonal relationships}

In the area of interpersonal relationships the indication was that the students were generally treated fairly by personnel. Grievances about poor treatment were however expressed toward ward sisters, senior nurses and the medical staff.

\section{Difficulties}

In the event of any personal or nursing difficulties during the course of their training, the results indicated that:

- in the case of personal difficulties, most students would seek the assistance of either their student colleagues, family or friends rather than that of other nursing personnel;

- in the case of nursing difficulties, most would solicit the assistance of their peers rather than approaching more senior nursing personnel.

\section{Intervention}

A very important finding was that $51,7 \%$ of the respondents felt that some form of intervention could have encouraged them to continue their training. Specific mention was made of intervention in the form of personal support - college staff could have taken measures to assist individuals and better team work and instruction at the practical level would also have contributed positively. Improved working and ser- vice conditions, for instance better hours of duty and an improved salary, would have encouraged some students to complete their training.

\section{Disillusionment}

In retrospect, $42,1 \%$ of the abandon group felt that nursing did not live up to their expectations and they were generally disillusioned with the profession.

\section{The most important reasons for abandonment}

In answer to the request for respondents to state the most important reasons for their abandonment of training, the results shown in Table 5 emerged. cant difficulties during the tirst period of training, abandonment might have been precipitated by the examinations towards the end of the first year. If any effort is to be geared to the prevention of the drop-out phenomenon intervention effort should thus reach it's peak during this time, particularly as $51,7 \%$ of respondents felt that some form of intervention could or might have encouraged them not to abandon their training. When one considers the respondents' most important reasons for abandonment $66,7 \%$ left because of service/working conditions, the college, wards/ departments and interpersonal relationships, and the nurses' home it becomes apparent that in general these are hospital related variables

\section{TABLE 5: ANALYSIS OF THE MOST IMPORTANT REASONS FOR ABANDONMENT OF TRAINING}

\begin{tabular}{|c|c|c|c|}
\hline VARIABLE & NUMBER & $\%$ & \\
\hline $\begin{array}{l}\text { PERSONAL REASONS } \\
\text { SERVICE AND }\end{array}$ & 62 & 33,3 & \\
\hline WORKING CONDITIONS & 46 & 24.7 & \\
\hline COLLEGE & 37 & 19.9 & \\
\hline $\begin{array}{l}\text { WARDS/DEPARTMENTS } \\
\text { AND INTERPERSONAL }\end{array}$ & & & 66,7 \\
\hline $\begin{array}{l}\text { AND INTERPERSONAL } \\
\text { RELATIONSHIPS }\end{array}$ & 31 & 16,7 & \\
\hline NURSES' HOME & 10 & 5.4 & \\
\hline
\end{tabular}

\section{Respondents' Recommen- dations}

An analysis of the respondents' recommendations regarding the areas which they would like changed at the hospital, should they recommence training is given in Table 6 . and, therefore, some attempt to redeem the situation appears necessary. The personal reasons area also needs to be considered for intervention.

Evidence suggests that the general service and working conditions

\section{TABLE 6: ANALYSIS OF RESPONDENTS' RECOMMEN- DATIONS}

\begin{tabular}{l|c|c}
\hline AREA & NUMBER & $\%$ \\
\hline SERVICE/WORKING CON- & 96 & 49,7 \\
DITIONS & & \\
STAFF RELATIONSHIPS & 60 & 31,1 \\
ON THE WARD & 22 & 12,2 \\
NURSES' HOME & 15 & 7,8 \\
COLLEGE & \\
\hline
\end{tabular}

\section{DISCUSSION}

The demographic data shown in Tables 1 and 2 suggests that the students generally abandon the course towards the end of the first year. The drop-out rate was very high in this period. The first year group comprised mostly ot school leavers. If they had experienced any signifi- (duty hours, weekend-work and night-duty, as well as salary) has a significant negative effect on job satisfaction. This problem existed in spite of the prior recognition by $65,5 \%$ of students that nursing would effect their social life. This is indeed a great problem and to suggest an easy solution would cer- 
tainly be foolhardy. Robinson $(1973)^{3}$ indicates that by increasing staff recruitment fundamental problems of job satisfaction are not necessarily solved so that existing conditions of a lack of staff are perpetuated.

Regarding salary, $95,2 \%$ of the respondents were of the opinion that registered nurses were inadequately paid. This is perhaps an important variable to a group already beset with problems during training. To pursue the course for another two years and then to be faced with generally poor working conditions and an inadequate salary may not be a very encouraging prospect for the future.

Academically the college prepared most of the students $(67,6 \%)$ adequately for implementing theory into practice. In the practical setting most $(77,9 \%)$ felt that they were adequately helped and consequently found working in the wards a rewarding experience. However, $23,4 \%$ of the group felt inadequately prepared for the wards and $32,5 \%$ stated specifically that they abandoned their training for reasons related to the college. Here one would question the general cognitive abilities and aptitude of the abandon group. Perhaps nursing was a wrong career choice from the outset. Therefore, this area needs further intensive investigation to determine specifically which factors are involved. Psychological testing could assist in providing valuable information for further research into the drop-out phenomenon.

The area of interpersonal relations manifested itself throughout. This is important as it may well be that the first year students require more personal support and understanding than they seem to be receiving at present, especially as evidence suggests that this is a time of high stress during which most abandonment occurs. It appears that this group is particularly sensitive to critical attitudes. It may be relevant to compare the attitudes of students and registered nurses. Is it possible that registered nurses accept criticism more readily than students and also that more subtle variables may be involved with the registered group? Questions such as these remain unanswered and need further investigation.

When the students experienced significant personal difficulties, or difficulties associated with nursing, most would not seek the assistance of senior nursing pesonnel, but would rather solicit the assistance of their peers. Here too, more intensive research is necessary to establish the reasons for this occurrence. Is there, perhaps, a lack of identity outside their student peergroup?

From the above it is obvious that more intensive research is necessary, in numerous areas, to evaluate the recruitment and drop-out phenomenon in nursing education. What this study has indicated is that there are problems encountered by student nurses which need to be dealt with at two levels. Firstly, within the hospital and secondly, at a wider level to improve the conditions of service.

\section{CONCLUSION}

From the results obtained in this survey, it is clear that:

- the drop-out rate of student nurses is high $(37,3 \%)$ which suggests that almost four out of ten students recruited would abandon the course particularly toward the end of the first year of training;

- that numerous variables were involved in influencing the respondents' decision to abandon the course.

An important demographic characteristic was that the majority of the total group recruited comprised of school-leavers. When the abandon group was compared with the non-abandon group regarding previous work experience, no significant difference between the two groups was found.

Regarding the variables that became apparent in this survey the following were of importance:

- significant dissatisfaction was expressed towards general service and working conditions (salary, hours of duty, weekend and night-duty);

- a small but significant group found difficulty in coping with the academic demands of nursing;

- poor interpersonal relationships appeared to contribute generally towards the decision to abandon the course;

- lack of personal and professional support was expressed by the abandon group;

- some form of intervention may possibly have prevented abandonment.

\section{RECOMMENDATIONS}

It has been demonstrated by this relatively modest survey that further research is necessary to examine more specifically and comprehensively the variables suggested in this study, in order to draw more definite conclusions. However, preliminary suggestions and recommendations appear feasible. These are:

- the improvement of the general working/service conditions of the nursing profession;

- an improvement in the interpersonal relationships at different levels;

- more personal and professional support for student nurses;

- a counselling service for student nurses with personal problems;

- to make use of various psychological tests to determine and possibly discriminate between stayers and leavers in terms of their cognitive abilities, personality, interest and attitudes.

Thanks are due to the following: - Greys Hospital and the Natal Provincial Administration for permission to conduct this study;

- The Department of Health and Welfare.

- Special thanks to all the ex-students of Greys Hospital as without them this study would not have been possible.

BIRCH, J , To Nurse or Not to Nurse. The Royal College of Nursing and National Council of Nurses of the United Kingdom. London. 1975.

MACQUIRE, J.M., Threshold to Nursing. Bell. London. 1969.

ROBINSON. I.D., Factors affecting the drop-out of Trainee Nurses at Oakleigh Hospital. New Zealand Medical Journal. 1973. 